LSE 'Europe in Question’ Discussion Paper Series

\title{
Political Contestation in the Shadow of
}

\section{Hierarchy}

Niclas Meyer

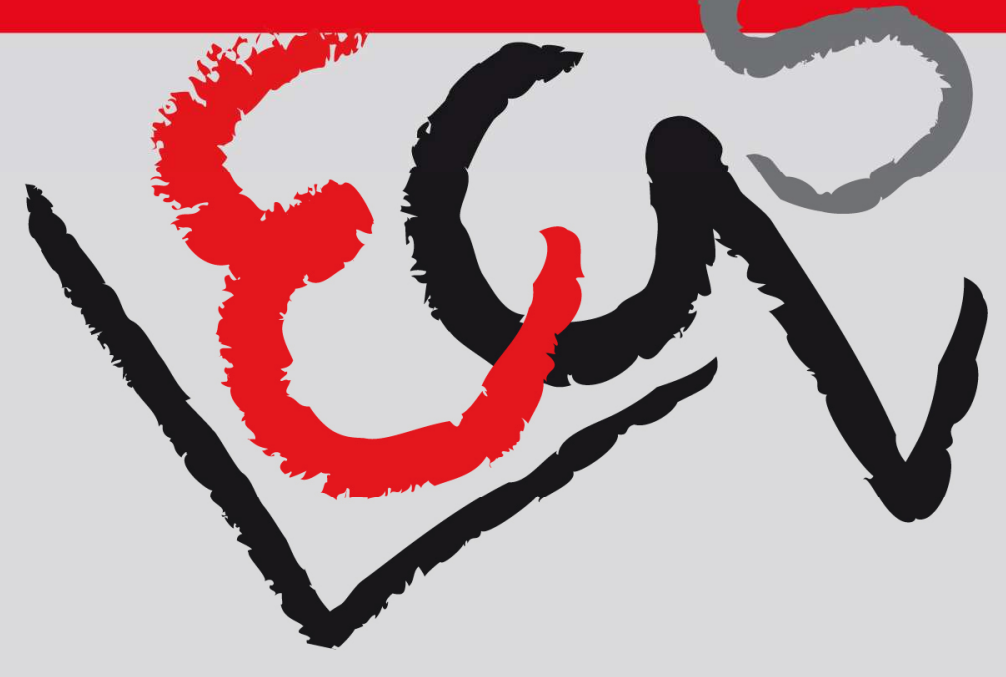




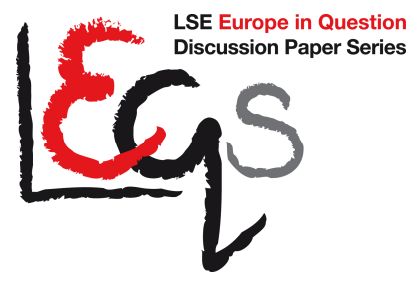

\section{Editorial Board}

Dr. Joan Costa-i-Font

Dr. Vassilis Monastiriotis

Dr. Jonathan White

Ms. Katjana Gattermann

All views expressed in this paper are those of the author and do not necessarily represent the views of the editors or the LSE.

(C) Niclas Meyer 


\title{
Political Contestation in the Shadow
}

\section{of Hierarchy}

\author{
Niclas Meyer*
}

\begin{abstract}
In the public policy literature, there is a widespread belief that industry self-regulation would only take place - and lead to satisfactory results - if industry was faced with a credible threat of hierarchical government intervention. At the example of intermodal transport standardization, however, this paper demonstrates that this does not have to be the case. It may even have a counterproductive effect by exposing self-regulatory processes to political contestation.
\end{abstract}

Keywords: Shadow of hierarchy, self-regulation, private governance, technical standardization

* London School of Economics

European Institute, Houghton St, London WC2A 2AE, UK

Email: n.meyer@lse.ac.uk 


\section{Table of Contents}

1. Introduction

2. European Intermodal Transport Standardization

3. Explaining the Unexpected and Counterproductive Effect

4. Conclusions

References

Appendix

\section{Acknowledgements}

For feedback and comments the author would like to thank Mareike Kleine, Christa van Wijnbergen, Waltraud Schelkle and Damian Chalmers as well as the participants of the European Institute Lunchtime Seminar as well as the 61st Political Science Association Annual Conference where earlier versions of this article were presented. Moreover, the author would like to express his gratitude to 18 interviewees, which granted invaluable insights into the world of intermodal transport standardization. 


\section{Political Contestation in the Shadow}

\section{of Hierarchy}

\section{Introduction}

In the public policy literature, there appears to be a widespread assumption that industry self- or co-regulation would only occur-and lead to satisfactory results-where industry was faced with a credible threat of hierarchical interventions through legislative or executive decisions. Assuming that industry wants to prevent such intervention, proponents of this 'shadow-of-hierarchy' hypothesis argue that the threat of revising existing or introducing further secondary legislation would prompt industry to engage in self-regulation.

While this argument has been around for a while, the most recent version of the shadow-of-hierarchy hypothesis was formulated specifically in response to the increasing attention to new forms of governance that include private actors and/or do not rely on conventional public policy-making processes (Héritier \& Lehmkuhl, 2011, see). In the face of the rapidly advancing pace of technological change and economic internationalization, public actors are often considered unable to provide the governance functions they used. As they are still commonly expected to provide these functions, they increasingly have to rely on private actors. Although public actors may be dependent on private rule-makers and although there appears to have been a large rise in such new, private modes of governance, the recent shadow-of-hierarchy literature suggests that private governance was not as private as it seemed, for there would not be any private governance if it was not for the public 
shadow of hierarchy. If one scratched the surface of these new, nonhierarchical modes of governance, Rhodes and Visser (2011, p. 123) argues, one is likely to find old, hierarchical modes underneath. Without the shadow of hierarchy, this literature suggests, self- or co-regulation would not take place. It is considered a necessary condition for self- or co-regulation to succeed.

The case of intermodal transport standardization, which is discussed in this paper, however, demonstrates that this does not need to be case. After industry self-regulation had already led to first positive results, the European Commission sought to promote this process by issuing an implicit though credible threat to introduce draconian legislation. Immediately after this shadow of hierarchy was formulated, however, the self-regulatory process began to fail. Instead of facilitating private governance, this case suggests that the shadow of hierarchy merely appears to have exacerbated the collective action and decision-making problems inherent to private rule-making processes. Instead of representing a necessary condition of self-or coregulation, it appears to have been a prohibiting condition.

The threat of hierarchical intervention was formulated in comparatively favorable circumstances. Therefore, this outcome is rather puzzling. The Commission's threat to intervene through the introduction of secondary legislation was perceived to be very credible. Therefore, the main necessary condition--i.e. credibility - of the shadow-of-hierarchy hypothesis appears to have been met (Héritier \& Eckert, 2008, p. 116), further underlining the question why the shadow of hierarchy failed to have the desired and predicted effect. Moreover, governmental actors, including the Commission, European Parliament and Council, could build on a comparatively high degree of control over the private governance process, which represents 
another necessary condition identified by the recent shadow of hierarchy literature.

The remainder of this paper is organized as follows. Section 2 summarizes the case of self-regulation in the intermodal transport industry and the effect of the sudden formulation of the shadow of hierarchy. Section 3 tries to explain the shadow's counterproductive effect and draw generalizable conclusions from the case study.

\section{European Intermodal Transport Standardization}

The case of self-regulation discussed in this article took the form of private industry standardization. Technical standards are generally developed in private, industry-driven standards-writing organizations, which stand outside of-and tend to be completely independent from-conventional policy-making processes. Although technical standards are usually unnoticed unless they are missing - as anyone that will be able to confirm who, while traveling, has been confronted with an incompatible electricity socket-they fulfill a variety of important governance functions. At the one end of the spectrum, reference and quality standards signal consumers that a specific product or service is "fit for purpose" (ISO, 2005, p. 10), complying with a set of health, safety, or environmental quality levels etc. Thereby technical standards significantly increase the efficiency of economic transactions by resolving information asymmetries regarding the quality of products between buyers and sellers (Akerlof, 1970). On the other hand, compatibility and interface standards govern the technological and transactional interconnectivity between different goods and services (David and Greenstein 1990; David and Steinmueller, 1994, p. 218). 
In this case, technical standardization took place in CEN (European Committee for Standardization) and more specifically its Technical Committee for Swap bodies for combined goods transport (TC119). The purpose of technical standardization was to improve the integration of air, rail, road, inland waterways, short and deep-sea transport modes by developing a loading unit-or shipping container-which was compatible with the needs and requirements of all modes of transports thus increasing intermodal interoperability. According to the notion of 'intermodalism', which constituted the dominant policy paradigm of the 1990s and the early 2000s, the combination of multiple modes of transport was considered necessary to take advantage of each mode's inherent economies to unleash unused capacities, to relieve pressure on the existing infrastructure, and to reduce carbon emissions, road congestion and accidents (EC, 1995).

Until the early 1990s, a large variety of distinctly different and thus incompatible loading units circulated through the European transport system. The standardized international shipping container was hardly used in intraEuropean transport. The problem with the international shipping container, which was standardized by the International Standardization Organization (ISO) and which, in the words of Levinson (2006), "made the world smaller and the world economy bigger," was that it was incompatible with the shipping pallets commonly used in Europe. ${ }^{1}$ As illustrated by Figure 1, the ISO Series 1 containers sacrifice valuable cargo space. For the cost of transporting and handling full or only half-full loading units tends to be almost the same, the international container has a competitive disadvantage against containers that are optimized for the transportation of pallets. ${ }^{2}$ At the

\footnotetext{
1 The international container standard specified the dimensions, handling equipment, terminology, ratings and identification markings of containers. Four different containers of 10, 20, 30 and 40 feet were adopted.

2 The price that container terminals charge per crane lift, for instance, is fixed and also labor costs, the highest cost factor in road transport, are the same.
} 
same time pallets could not be adapted to the new container standard. Although wooden pallets would be relatively inexpensive to replace, assembly lines and warehouses across Europe were already optimized for the handling of pallets. Adapting these to the international container standard, however, would be prohibitively expensive. Therefore, the ISO container never gained any significant market shares in intra-European transport. In international transport-including the transport in and out of Europehowever, it is the uncontested de facto standard.

Instead of developing a single common standard for intra-European transport in response to the incompatibility of the international container standard with European pallet standards, however, European industry responded in a largely uncoordinated way. Multiple, mostly incompatible, loading units were developed, without paying sufficient attention to loss of efficiency that this meant for the entire transport system as a whole. Operators from each mode of transport-road, rail, short sea and inland waterway-largely followed their own technical preferences in the development of new loading units, as summarized in Table 1. While sea and inland waterway transport operators were interested in stack-ability, for instance, road haulers sought to minimize the tare weight of loading units in order to reduce fuel consumption. Therefore, they tend to favor light-build loading units and were not interest in stack-ability. ${ }^{3}$ Deep-sea transport operators, however, did not prefer pallet-wide containers because all modern containers vessels are nowadays fitted with cellular frames that increases load stability at sea and accelerate the (dis)charging process in port. Instead, they tend to have a strong preference for extra high loading units-also known as 'high-cube' containers. Rail transport operators, in turn, had no interested in stack-ability

\footnotetext{
${ }^{3}$ This lead to the development of the swap body. This un-stackable loading unit owes its name to four up-folding legs that make it possible to 'swap' them from one trailer to another, or to leave them at a loading bay, without the help of a crane.
} 
either but required lift-able loading units.

The heterogeneity of loading units and the lack of common standards had devastating consequences for the European economy and environment. It significantly increases transportation costs. ${ }^{4}$ The lack of interoperability between systems often required the reloading of fright from one loading unit to another, whenever a national or modal boundaries were crossed, thus defeating the purpose of containerization. The excessive heterogeneity of loading units also undermined automation, jeopardizing potential efficiency increases even further. Moreover, the lack of standardization significantly increases the number of empty back-hauls, exacerbating the problem of traffic congestion. Europe's trucks run empty $35 \%$ to $40 \%$ of the time (Freudmann, 1999). And in lack of interoperability standards it lead to an underutilization of non-road modes of transport. According to Eurostat (2007, p. 68) 72\% of all inland fright transport is still carried out by road. This did not only lead to more road congestion but also increased the number of accidents and environmental pollution. ${ }^{5}$

By the mid-1990s, however, a group of firms that had specialized in the combination of rail and road transport-and therefore became known as the combined transport industry-decided to do something about lack of common standards. As the transfer of freight between different modes was at the core of their business, the combined transport operators had a natural interest in intermodal interoperability. Therefore, they started to meet in the TC119 of CEN to start working on common standards.

After long negotiations within the TC119, the standard-setters eventually

\footnotetext{
${ }^{4}$ The European transport industry accounts for 7\% of the EU's gross national product (GNP), 7\% of all jobs, which is quite large considering that it is merely meant to be an intermediary (Eurostat, 2007).

5 The transport sector accounts for $30 \%$ of the Community's energy consumption and the maintenance and adaption of the transport infrastructure ties $40 \%$ of member states' public investment (Eurostat, 2007).
} 
came to a preliminary agreement on the basic parameters of a long and a short intermodal loading unit, in May 1997 (see Deutsche Verkehrszeitung, 1997). Both versions appeared to represent the state-of-the-art in container design. Despite the fact the units clearly reflected TC119's bias toward combined transport operators - which mainly manifests itself in the units' comparatively large width; waterborne transport operators would have preferred narrower units - both loading units constituted a vast improvement compared to the existing units used in intra-European transport. The proposed units' increased loading capacity should have outweighed all short term adaptation costs. In contrast to the comparable ISO container, which can only accommodate a maximum of 25 pallets, the proposed unit would have been able to accommodate up to 33 pallets. That would have meant an increase of $21 \%$ in transport capacity. Moreover, the units were designed to be stackable and top-liftable-crucial requirements for canal and sea transport. All participants of the intra-European transport community could be expected to benefit from the introduction of such a loading unit standard. Moreover, it was estimated that an average drop in overall logistics cost by two percent could be achieved for containerized dry cargo moving four hundred kilometers or further and that the final delivered price of many consumer goods could be reduced by $0.02 \%$ to $0.2 \%$ (ICF Consulting, 2003, p. 4).

In the long run, all modes of transport should have benefited from the formal adoption of these units as European standards. Especially the waterborne transport modes-though facing short term adaptation costs-should have been among the largest beneficiaries of the new units. The units' pallet compatibility, stack-ability and top-lift-ability should have made it easier to integrate these modes into the transport mix. The canal shipping industry had traditionally suffered from the frictional costs involved in loading cargo onto and off canal barges. Therefore, the canal shipping industry was-and still 
is-operating below capacity while the capacity of the European road network had long been exceeded. The units' stack-ability and, especially, their top-lift-ability were bound to decrease these frictional costs.

In order to support the standardization process, the European Commission, which had long been concerned about the lack of intermodal standards, ${ }^{6}$ intervened in 2003. It formulated a threat to introduce coercive secondary legislation mandating and/or subsidizing compliance with a single common European Intermodal Loading Unit (EILU) standard if industry was not going to agree to adopt and comply with a single common standard, i.e. the specifications developed by the TC119. The Commission expected the threat to prompt the combined transport community to intensify their standardization work and the remaining participants of the transport industry to adopt the developed standards. Based on the shadow-of hierarchy literature the European Commission had all reason to expect this strategy to work.

This shadow of hierarchy was formulated in the context of a proposal by the European Commission to recognize the specifications already developed by the combined transport community as official European standards (EC, 2003). Although the formal status would have entitled the unit to free circulation around the single European market, ${ }^{7}$ it would not have obliged industry to adopt the standards, leaving their voluntary status untouched. ${ }^{8}$ The proposal

\footnotetext{
${ }^{6}$ See EC $(1995 ; 1997$, p. $8 ; 2001)$.

7 The standard would have been presumed to comply with the General Product Safety Directive 2001/95/EC and the Directive 96/53/EC on vehicle weights and dimensions. Individual Member States would not have been easily been able to restrict the circulation of compliant products.

${ }^{8}$ It is clearly stated in the proposal that all types of loading units, including both swap bodies and iso Series 1 containers, can remain on the market as long as they comply with the safety and security norms defined in the international Convention for Safe Containers (1972) (Article 2(b) and Annex I), of which all EU member states are signatories. While the Convention for Safe Containers already applies to iso Series 1 containerss, swap bodies have been so far been exempted. Only the new EILU, however, would additionally have to comply with the dimensions and handling features specified in the proposed Directive (Article 2(c) and Annex II). The proposal thus is not the enactment of the threat attached to it.
} 
itself was thus mostly symbolical. However, the Commission attached an implicit threat to it suggesting that it would introduce further legislation providing positive and/or negative sanctions to promote compliance with loading unit standards. The Commission never clarified what steps it would take. As a result, rumors soon emerged within in the industry that the Commission might allow Members States to provide tax incentives (Deutsche Verkehrszeitung, 2004), that eligibility to Marco Polo funding might be made conditional on the use of and compliance with the standard, and that all noncompliant loading units would only be allowed to remain on the market for a transition period of several years.

The Commission actively nourished these speculations by refusing to clarify its future strategy. In a consultation paper, for instance, the Commission had formulated the expectation that the old loading units would gradually disappear from the market during the following five to fifteen years, without specifying whether this was going to happen through regulatory intervention or market forces alone. At an open forum organized by CEN, the Commission skillfully ignored all questions regarding this issue. ${ }^{9}$

Over the years the Directorate-General for Energy and Transport (DG TREN) had gained the reputation of superimposing legislation on industry. According to an interviewed Commission employee, DG TREN had lost a lot of credit with industry due to this approach. ${ }^{10}$ Furthermore, the Commission had accumulated broad competences in transport policy. ${ }^{11}$ As a result, industry perceived the shadow of hierarchy to be very credible, despite the

\footnotetext{
${ }^{9}$ CEN (2003), EC (2002), Interview 8 with a representative of the combined transport industry (2009).

${ }^{10}$ Interview 2 with a representative of the European Commission, 2009.

${ }_{11}$ European Union (EU) Transport policy dates back to the 1958 Treaty of Rome (Article 3f and Title V). Over the years, the Commission had gained a considerable amount of competences in this domain. Article 71(1) provides a legal basis for measures to improve transport safety, an area where it shares jurisdiction with the Member States. Article 80(2) also provides a legal basis to include the maritime sector.
} 
fact that it had never been made explicit.

The credibility of the Commission's threat was furthermore reinforced by the procedural circumstances in which the Commission formulated the shadow of hierarchy. Its initial proposal to recognize the units developed by the combined transport community as official European standards was based on the New Approach procedure. This legislative innovation from 1985 (European Council, 1985) was meant to allow European policy-makers to gain greater control over private standardization processes. In contrast to the 'old approach,' which foresaw a harmonization of technical regulations and barriers to trade at the legislative level, the New Approach was meant to delegate this task to private standard-setters while Member States retained a high degree of control over the private standardization process (see Egan, 1998). Through the 'essential requirements,' that the standard-setters had to comply with, Member States could control the scope, rigor, direction and content of the standardization process. According to the recent shadow-ofhierarchy literature, a high degree of formal control is supposed to be instrumental for the credibility of the shadow of hierarchy.

In light of the credibility of the Commission's threat and the high degree of control that it awarded the European policy-makers, the shadow of hierarchy should thus have been expected to prompt an intensification of the European transport industry's standardization efforts. This expectation is amplified by the facilitating circumstances that the private standardization process had almost been completed by the TC119 community already. Industry simply needs to adopt the specifications already developed. Furthermore, the introduction of the loading units specified in the TC119 seemed to provide large and relatively evenly spread gains to all participants of the intraEuropean transport industry. 
In practice, however, the shadow of hierarchy appears to have had the opposite effect. First, the result was that many actors that were previously not involved in the standardization process suddenly started to participate. If the adopted standard was ever to become mandatory, actors wanted to make sure that the standard was aligned with their own technical preferences or simply to prevent it from being adopted. Actors that had previously shied away from the high costs of participating, such as the road, short-sea and inland waterways operators, joined the standardization process. This led to a significant increase in the number and heterogeneity of participants (see Table 1). The consensus that had existed within CEN and within the policy arena was destroyed. As a result CEN never called for a vote on the issue. It was clear that there no longer was a sufficient majority within.

Outside of CEN, the opponents of the EILU standard also used the publicdecision making process to raise their voice. The public policy-making process turned out to be much more accessible then the private decisionmaking process within CEN's TC119. Unlike the latter, the former did not require any significant financial commitments and technical expertise from the opponents of the EILUs standard. A representative of the European Barge Union, for instance, suggested that the inland-waterway operators would neither have the time, resources nor expertise to participate in the standardization process. ${ }^{12}$ In the political debate, however, the operators were able to play an active and influential role through the European Barge Union.

The public decision-making process provided the EILU opponents with an opportunity to challenge the proposed standard on two levels. First, they tried to undermine the legitimacy of the TC119 community and the Commission's proposal by emphasizing the redistributive implications of the

12 Interview 14 with a representative of the inland waterway industry (2009). 
proposed standards redistributive implications of technical standardization and by pointing out the weaknesses and inconsistencies in the TC119 community's argumentation to justify their technical choices. The European Barge Union, for instance, argued that because EILUs are wider than ISO containers many barges will only be able to place three instead of four loading units latter next to each other. This would mean a loss of loading capacity of $25 \%$. While this problem could be circumvented by adapting the design of barges, as suggested by the combined transport community, the canal transport operators argued that the EILUs were still too high for most bridges, ports and terminals. Therefore, the introduction of the EILUs would not only require massive private but also public investments (CEN, 2003; European Barge Union, 2004, pp. 19-21).

The deep-sea shipping operators, to mention a second example, pointed out another important weakness in the TC119 community's argumentation. The latter had consistently argued that the EILU cannot be compatible with both international containers as well as the pallets used in Europe. And since the latter where much more important in intra-European transport, it was argued, the EILU should sacrifice container compatibility. A representative of the deep sea shipper NEN-Norfolk line, however, pointed out that there was a way to achieve both by using the thin-wall technology developed by the container manufacturer GE SeaCo. ${ }^{13}$

Secondly, the EILU opponents used the debate to launch a counternarrative-co-modalism-against the dominant policy paradigm of intermodalism upon which the EILU proposal was based. In contrast to intermodalism, which implied the policy objective of modal shift and the forcing of fright off the road, co-modalism had the objective of maximizing

13 CEN (2003), Interview 13 with a participant of CEN's TC119 (2009), Interview 18 with a container manufacturer (2009). 
the efficiency of each mode of transport in its own right. The underlying logic of co-modality is that once each mode is allowed to achieve its full potential, fright traffic would automatically shift to the most efficient combination of modes. Instead of pushing freight traffic to what is perceived to be the most efficient combination of modes of transport, the new policy objective is to rely on the market pull transport volumes to the most efficient modes. ${ }^{14}$ In contrast to intermodalism, co-modalism does not provide a direct role for government intervention. The idea of co-modalism soon won many adherents. The road transport and shipping operators used this counter narrative to call for a revision of Directive 96/53/EC on vehicle weights and dimensions to permit alternative larger and longer loading units, such as the 45 foot containers and longer road-trains - the gigaliners - in intra-European transport (Brookes, 2006; Stares, 2006). ${ }^{15}$

Although the EILU opponents managed to point out important weaknesses of the EILU proponents' arguments, the EILU still factually remained a large improvement to the existing situation. As a result of this discourse, however, the combined transport community seemed to have lost control of the issue once the standardization process had shifted from the TC119 into the political arena. The alliance could no longer control the nature and terms nor the locus of and participants in the debate. And as it was no longer able to shape the standards according to their own technical and strategic preference, the alliance that was once providing the expertise and financial muscle for the standardization process lost interest.

\footnotetext{
${ }^{14}$ Interview b3 with a representative of the road haulage industry (2009), Interview b5 with a representative of the road haulage industry (2009).

15 The 45 foot container did not comply with Directive 96/53/EC because it exceed the allowed dimensions. The Directive stipulates $16,650 \mathrm{~mm}$ as the maximum permissible length for vehicles on Europe's roads, with a maximum load length of $13,600 \mathrm{~mm}$. The 45 foot container, however, is 13,720 meters long, exceeding the limit by no more than $80 \mathrm{~mm}$. To give industry a chance to slowly withdraw the 45 footers from the market, a 'grandfather clause' had been included into the Directive (Article 4(6)). This clause allowed Member States to permit the container on their roads for a transition period of ten years after September 1997.
} 
While the shadow of hierarchy raised the stakes of the game and thereby multiplied the number of actors involved, the formalization of legislative influence and control over the technical standardization process through the New Approach also caused a multiplication of veto points. The New Approach procedure required the European Parliament and the Council to agree to the essential requirements of the unit through the co-decision procedure before the standardization process could be formally delegated to CEN. This provided the EILU opponents with two extra veto points.

Road haulers and deep-sea shipping quickly managed to convince the Council not to support the proposal. After only one round of discussions, the Dutch Council presidency decided that the proposal did not have sufficient support and removed it from the agenda. ${ }^{16}$

The European Parliament (EP) initially endorsed the Commission's proposal but the deep-sea shipping operators, against the recommendation of the TC119, managed to convince the Parliament to decrease the EILU's external width, so that it would fit into the cellular frame of container vessels but would not be able to transport pallets (EP, 2004). ${ }^{17}$

Ironically, however, even the Commission was eventually transformed into an additional veto point. During the debate individual members of DG TREN embraced the counter narrative of co-modalism to advance their own agenda and position within the DG. Co-modalism was increasingly perceived by many in the Commission as a more pragmatic alternative to intermodalism. After a re-shuffling of units and responsibilities within DG TREN in consequence of the appointment of a new Commission, the proponents of Commission were suddenly stronger than the proponents of

\footnotetext{
16 Interview 3 with a representative of the road haulage industry (2009), Interview 5 with a representative of the road haulage industry (2009).

17 In its amended proposal from 2004, the Commission changed the width back to 2,550 $\mathrm{mm}$ (EC, 2004).
} 
intermodalism (Interview 2 with a representative of the European Commission, 2009). On March 25, 2008 the Commission finally withdrew the EILU proposal (Dahm, 2009; Wahl, January 23, 2009). Moreover, the new DG TREN 'reinterpreted' the relevant clauses of the Directive on dimensions and weights (EC, 2006) and permitted the 45 foot container. The Maritime Industries Forum had long pushed for this step (Brookes, 2006; Stares, 2006).

This drew the last nail into the coffin of the EILU. The dilution of the existing legislation on vehicle weights and dimensions rendered the EILU uncompetitive against larger loading units. The intra-European transport industry remained stuck with a large number of incompatible, though larger, loading units. Self-regulation had failed and the shadow of hierarchy appears to have had an unexpected and counterproductive effect.

\section{Explaining the Unexpected and Counterproductive Effect}

This Section investigates the question why the shadow of hierarchy failed to lead to the expected intensification of industry self-regulation, despite the presence of rather favorable circumstances. The case study of inter modal transport standardization appears to have revealed two weaknesses of the shadow-of-hierarchy hypothesis. First, it appears to overemphasize industry's desire to prevent regulatory interventions. The shadow-of-hierarchy hypotheses is based on the assumption that when it comes to regulation, industry's first preference was to thwart legislation (Bartolini, 2011, p. 9; Héritier \& Eckert, 2008, p. 1). “Firms-as a rule-shun public intervention into their economic activities," Héritier and Lehmkuhl (2011, p. 55) argue. 
Therefore, industry is expected to prefer self-regulation as the lesser evil to top down legislation or regulation for it provides industry with a greater flexibility and influence over the definition of regulatory measures (Boddewyn, 1992). To prevent legislative interventions competing companies would therefore be willing to collaboratively develop and adopt selfregulatory measures.

While it may be true that companies will seek to prevent the introduction of secondary legislation that will weaken their competitive position against their competitors, the public choice literature has shown that companies may be just as likely to actively demand legislative interventions where these provide them with a competitive edge over their competitors (Stigler, 1975; Becker, 1983; Peltzman, 1984). In the case of intermodal transport standardization some proponents of the EILU, such as the combined transport operators, may have welcomed the introduction of secondary legislation strengthening the deployment of and compliance with their preferred container standard. Moreover, companies can also be expected to prefer the level of governancehierarchical, self- or co-regulation - that provides them with the greatest influence over the outcome of these processes. Their preferences can be expected to depend on two factors: First, the structure of the market and firms' respective position therein; and secondly, their respective influence in the formulation of regulatory measures at the different levels of governance. Moreover, firms' regulatory preferences can also be expected to vary with regards to the content as well as the rigor of regulatory measures. Usually, there is a choice between several (self-)regulatory measures to achieve a certain regulatory objective. In the case of technical standardization, for instance, different technologies can be chosen as the technological basis for a common technical standard. However, technical standardization seems to be far from an exception. There appears to be an increasing number of cases 
where governmental actors merely specify what policy goals are to be achieved and leave the choice how to reach these goals to private firms themselves (Jordan, Wurzel, \& Zito, 2005, p. 483). As different firms tend to favor different measures to achieve these, this choice cannot be expected to be free of conflict. In short, the shadow-of-hierarchy literature's assumption that firms' first preference was to prevent regulation is too restrictive. It rarely seems to hold and if it does it is unlikely to apply to all industry participants.

Given the fact that self-regulation usually requires directly competing firms to agree to a common set of self-regulatory measures for self-regulation to succeed, the divergence of firms' regulatory preferences - regarding the level, rigor and content of regulation-should be expected to be constrained by significant decision-making problems. The definition and adoption of selfregulatory measures may fail-even where firms share a strong interest in the prevention of public legislation-if firms' regulatory preferences are incompatible. Therefore, the join-decision traps that are considered to constrain public decision-making (Scharpf, 2006), can also be expected to undermine private decision-making. This has been largely overlooked by the governance literature. Since there is an increasing number of cases where governmental actors only specify what goals are to be achieved and let industry decide how to achieve these goals (Jordan et al., 2005, p. 483), such decision-making problems can be expected to gain in prominence.

The second weakness of the shadow-of-hierarchy hypothesis appears to be that it neglects the crucial role of intransparency and exclusiveness in selfregulation. Given the heterogeneous preferences and given the decisionmaking problems that result from the former, the only situation in which companies are able to agree to common self-regulatory measures appears to be one where participation in self-regulatory processes is limited to a small group of companies that share a set of compatible preferences. For better or 
worse, exclusiveness thus appears to be a necessary condition of selfregulation. Where the number and heterogeneity of rule-makers is reduced, there is a larger scope for mutually acceptable agreements on common selfregulatory measures. Moreover, collective decision making in small and homogeneous groups firms tends to be facilitated by the fact that are more likely to realize their mutual dependence and replace strategic bargaining with more deliberative forms of interaction, such as learning and collective problem-solving Porter (1979, p. 215). In the case of intermodal transport standardization, for instance, the development of first technical specifications for a European loading unit through the TC119 was facilitated by the fact that it was dominated by the combined transport community and that most industry participants with diverging preferences were excluded from the development and decision-making process. The political science literature provides plenty examples of such exclusive circles such as policy monopolies (Baumgartner \& Jones, 1993), whirlpools, sub-governments, iron triangles (Freeman, 1955), issue networks, unitary advocacy coalitions (Sabatier, 1988) etc.

Exclusiveness commonly appears to be achieved in two ways. First, individual firms may deliberately choose not to participate in the definition of self-regulatory measures. Some firms may not have the necessary financial means and technical expertise. As suggested by Héritier and Lehmkuhl (2011, p. 55), self-regulation is costly to devise and implement (also see Börzel, 2007, p. 7). Other firms may choose not to participate out of rational ignorance. They may speculate that the process will either not succeed or that the eventual cost of adapting to the resulting self-regulatory measures will not exceed the cost of participating in the process to shape the measures according to their own preferences. As suggested by Bartolini (2011), participation in governance arrangements is by definition voluntary. “Opting 
out is always possible, provided one is willing to bear the costs" (Bartolini, 2011).

Secondly, exclusiveness may also be achieved through the active exclusion of rival companies from participation. Companies often have a strong interest in excluding their competitors from the process in order to be able to shape selfregulatory measures according to their own preferences. A particularly common strategy to promote and justify the limited stakeholder participation is to present the definition of self-regulatory measures as a purely 'technical' process and to deemphasize potential normative and (re)distributive implications (see Radaelli, 1999, p. 759). Another frequently used strategy is to link self-regulation to widely accepted political objectives such as health, safety, growth and competitiveness.

Despite their voluntary nature, a large number of 'rule-takers' tends to adopt the self-regulatory measures defined by the exclusive circle of rule-makers. Compliance tends to be driven by a variety of mechanisms, including:

- Incorporation into private contracts, as a defense against tort or as in insurance policies (Majone, 1996, pp. 23-26);

- $\quad$ Learning, mimetic isomorphism (DiMaggio \& Powell, 1991);

- $\quad$ Setting market expectations of safety and reliability; and

- Network effects that progressively increase the benefit of compliance with the number of compliant parties, as discussed above.

As a result of industry's heterogeneous preferences and the crucial role of exclusiveness in self-regulation, the formulation of the shadow of hierarchy is likely to have two consequences.

First, it can be expected to multiply the number of actors participating - i.e. 
veto players-in the self- or co-regulatory processes. The shadow of hierarchy raises the stakes of the game. Expecting that such interventions will increase the chances that they may eventually have to comply with the given self-regulatory measures, firms will actively push into the definition process in order to make sure that the resulting measures are in line with their preferences. As suggested by the shadow-of-hierarchy literature, firms can be expected to overcome their collective action problems and start to participate (Börzel, 2007, p. 6; Héritier \& Lehmkuhl, 2011, p. 2; Mayntz \& Scharpf, 1995, pp. 21-23). Even firms that previously chose to remain rationally ignorant can be expected to start to participate. For that reason the canal, rail and deep sea transport operators started to participate in the standardization process after the Commission's threat to subsidize and mandate compliance with the EILU. Moreover, the raised stakes of the game should make it more profitable for firms that have less to loose from hierarchical intervention and less to gain from self-regulation to hold out agreement against firms that have more to gain from self-regulation. Given the heterogeneity of regulatory preferences, an increase in the number participants can be expected to reduce the scope for a mutually acceptable agreement on common regulatory measures.

While the increase participation may be desirable from democratic standpoint, it causes the shadow of hierarchy to have the unintended effect of exacerbating the inherent decision-making problems of industry selfregulatory processes. Industry will be less likely to agree to common selfregulatory measures. This is diametrically opposed to the shadow-ofhierarchy hypothesis that "[g]overnment envisaging first legislative steps or the tightening of existing legislation prompts self-regulation by industry" (Héritier \& Eckert, 2008, p. 116).

Secondly, hierarchical interventions, as in the form of negative or positive sanctions, open up new veto points to actors that have less to gain or even 
expect to loose from self-regulation. In pluralist political systems, the enactment of the threat to introduce sanctioning legislation or executive decisions conventionally requires the consent of-or is subjected to the scrutiny of-other public actors, such as Parliaments and courts. These provide opponents of a particular self-regulatory arrangement or selfregulation in general with effective veto points. In the European Union, secondary legislation is generally introduced through the co-decision procedure, which involves the European Council and Parliament. Both have veto powers. In the case of intermodal transport, the enactment of the threat to mandate or subsidize compliance through the introduction of secondary legislation, too, would have directly involved the European Parliament and Council. Both institutions turned out to be quite receptive to the arguments of the EILU opponents and prevented the Commission from taking further steps in the direction of forcing industry to comply with the EILU standard.

The higher the degree of formalized public control over the performance of private self-regulators, the more likely the opponents of self-regulation are to appeal to public actors. This, too, is directly opposed to the hypothesis by Héritier and Eckert (2008, p. 117) that the more rigorous the instruments of control over industry, the better the self-regulation would perform. While this may underline the credibility of the shadow of hierarchy, it also provides the opponents of self-regulation with a strong incentive to appeal to these actors. In the case of intermodal transport standardization, the New Approach procedure lent the European Parliament and Council the authority to define the objectives and content of the standardization process. Therefore, the EILU opponents lobbied both institutions to veto the Commission's plans.

This shows that in contrast to self-regulatory circles, the political arena operates according to completely different principles. First, participation costs are comparatively modest, which allows a broad number of actors and 
interests to participate in the political debate. ${ }^{18}$ Secondly, influence in the political arena does not depend on technical expertise or the ability to conceal one's interests in technical terms, as required in standardization committees (Schmidt \& Werle, 1993, p. 15; Sirbu \& Zwimpfer, 1985). To the contrary, technical sophistication rather seems to decrease actors' chances of being heard (Lehmann, 2009). Instead, the political arena favor actors with the capacity to link issues to widely accepted core political objectives that are hard to contest and can be easily communicated, such as growth, competitiveness, employment, sustainability, security etc., and the ability to provide political capital to improve the reputations and profiles of elected officials in their constituency and within the political institutions. Thirdly, political debates appears to emphasize normative (Easton, 1976, p. 129) and (re)distributive (Lasswell, 1958) implication of issues rather than joint problem solving. As a result the standardization process was perceived as a zero-sum rather than a positive game.

\section{Conclusions}

This paper shows that the looming shadow of hierarchy does not necessarily need to facilitate industry self-regulation. Where industry's regulatory preferences are heterogeneous and self- or co-regulation usually takes place in exclusive circles of limited participation, the shadow of hierarchy is likely to have an unintended and counterproductive effect. It will not lead to an intensification of self- or co-regulation. Instead the shadow of hierarchy can be expected to expose self-regulatory processes to political contestation by

\footnotetext{
18 In the European Union, for instance, the EP, Commission and Council provide access to a vast range of stakeholders including 300 firms and 843 trade associations, 429 citizen interest bodies, 198 regions, 103 think tanks, 115 law firms, and 153 public affairs firms (Greenwood, 2005; Landmarks Publications, 2003; Coen \& Richardson, 2009).
} 
multiplying the number of veto players and veto points involved in the decision-making process.

However, this should not be mistaken as an argument for laissez faire. Governmental actors may very well have an important role to play in industry self-regulation, yet the threat of hierarchical intervention is neither a sufficient nor necessary for self-regulation to succeed. 


\section{References}

Akerlof, G. (1970). The Market for 'Lemons': Quality Uncertainty and the Market Mechanism. The Quarterly Journal of Economics, 84(3), 488-500.

Ayres, I, \& Braithwaite, J. (1992). Responsive Regulation: Transcending the Deregulation Debate. New York: Oxford University Press.

Bartolini, S. (2011). New Modes of European Governance: An Introduction. In A. Héritier \& M. Rhodes (Eds.), New Modes of Governance in Europe: Governing in the Shadow of Hierarchy (pp. 1-18). Palgrave Macmillan.

Baumgartner, F. R., \& Jones, B. D. (1993). Agendas and instability in American politics. Chicago, IL: University of Chicago Press.

Becker, G. (1983). A theory of competition among pressure groups for political influence. The Quarterly Journal of Economics, 98(3), 371.

Bercusson, B. (1993). European labour law and sectoral bargaining. Industrial Relations Journal, 24(4), 257-72.

Boddewyn, J. (1992). Global Perspectives on Advertising Self-regulation: Principles and Practices in Thirty-eight Countries. Westport, CT: Quorum Books.

Börzel, T. (2007, June 04). Regieren ohne den Schatten der Hierarchie. Ein modernisierungstheoretischer Fehlschluss? In T. Risse \& U. Lehmkuhl (Eds.), Regieren ohne Staat? Governance in Räumen begrenzter Staatlichkeit (Vol. 10). Schriften zur GovernanceForschung. Baden-Baden: Nomos.

Börzel, T. (2009). Coping with Accession to the European Union: New Modes of Environmental Governance. Basingstoke: Palgrave Macmillan.

Braithwaite, J. (2000). The New Regulatory State and the Transofrmation of Criminology. British Journal of Criminology, 40(2), 222-238.

Braithwaite, J. (2005). Neo-Liberalism or Regulated Capitalism? RegNet Occasional Paper, 5.

Brookes, E. (2006, Aug. 30). A welcome rethink on $45 \mathrm{ft}$ boxes. Lloyd's List, 10.

CEN.(2003, Oct.). Report of open CEN Forum on Short Sea Shipping -Intermodal Loading Units (ILU) in Brussels, October 2, 2003. Retrieved June 29, 2009, from http://www.cennorm.be

Coen, D., \& Richardson, J. (2009). Learning to Lobby the European Union: 20 Years of Change. In D. Coen \& J. Richardson (Eds.), Lobbying the European Union: Institutions, Actors and Issues (pp. 3-18). Oxford: OUP.

Convention for Safe Containers. (1972). International convention for safe containers, adopted on 2/12/1972, entered into force on 6/9/1977 and amended in 1981, 1983, 1991 and 1993 (www.imo.org). Retrieved June 29, 2009, from International Maritime Organisation: www.imo. org

Dahm, C. (2009, Jan. 08). Neue Strategie auf die Fahne geschrieben. Deutsche Verkehrszeitung.

David, P. A., \& Greenstein, S. (1990). The economics of compatibility standards: An introduction to recent research. Economics of Innovation and New Technology, 1, 3-41. 
David, P. A., \& Steinmueller, W. E. (1994). Economics of compatibility standards and competition in telecommunication networks. Information Economics and Policy, 6, 217-241.

Deutsche Verkehrszeitung. (1997, June 07). Weichenstellung im Europaeischen Normenausschuss Europaeischer Container fuer den Short-Sea-Verkehr.

Deutsche Verkehrszeitung.(2004, Feb. 24). Die neue Box muss sich am Markt durchsetzen.

DiMaggio, P. J., \& Powell, W. W. (1991). The iron cage revisited: institutional isomorphism and collective rationality in organizational fields. In

Easton, D. (1976). The political system (2nd ed.). New York: Alfred A. Knopf.

Eberlein, B., \& Grande, E. (2005). Reconstituting Politcal Authority in Europe: Transnational Regulatory Networks and the Informalization of Governance in the European Union. In E. Grande \& L. Pauly (Eds.), Complex sovereignty: reconstructing political authority in the twenty-first century (pp. 146-167). Toronto: University of Toronto Press.

Egan, M. (1998). Regulatory strategies, delegation and european market integration. Journal of European Public Policy, 5(3), 485-506.

European Barge Union. (2004, Sept.). Intermodal loading units - harmonization and standardization initiative. Comments on the EC communication on the promotion of Short Sea Shipping, March 22. Retrieved July 18, 2009, from www.unece.org/trans/wp24/wp24infdocs/.../id04-04e.pdf

European Commission [EC].(1995). The Common Transport Policy Action Programme 19952000, COM(95)302 of 12 December 1995.

EC. (1997). Intermodality and Intermodal Freight Transport in the European Union. A systems approach to freight transport. Strategies and actions to enhance efficiency, services and sustainability. COM (97) 243 final, 19.05.1997. Retrieved Apr. 14, 2009, from http://aei.pitt. edu/4717/01/000811_1.pdf

EC. (2001). European Transport Policy for 2010: Time to decide. White Paper. Retrieved Apr. 7, 2009, from http://ec.europa.eu/transport/ white_paper/documents/doc/lb_com_2001_0370_en.pdf

EC. (2003). Proposal for a Directive of the European Parliament and of the Council on Intermodal Loading Units. COM (2003) 155 final, April 7, 2003.

EC. (2002). Consultation Paper on Intermodal Loading Units -Harmonisation and Standardisation Initiative. Brussels, April 17.

EC. (2004, Apr.). Amended proposal for a Directive of the European Parliament and of the Council on intermodal loading units. COM(2004) 361 final. Brussels, April 30, 2004.

EC. (2006). Commission staff working document on on the continuous carriage of 45' containers in national road transport. Brussels, November 27. SEC(2006) 1581. Retrieved Apr. 14, 2009, from ec.europa.eu/ transport/.../45_containers/.../2006_11_27_staff_working_sec_2006_1581_en.pdf

European Council. (1985). Council Resolution on a new approach to technical harmonisation and standards. OJ C 136, 4.6.1985, p. 1-9.

European Parliament. (2004, Jan.). Report on the proposal for a European Parliament and Council directive on intermodal loading units (COM(2003) 155 - C5-0167/2003 - 2003/0056(COD)). Committee on Regional Policy, Transport and Tourism. Rapporteur: Ulrich Stockmann. FINAL A50016/2004, 28 January. 
Eurostat. (2007). Panorama of transport. Retrieved Apr. 23, 2009, from Eurostat, European Commission DG Energy, and Transport: epp. eurostat.ec.europa.eu/cache/ITY_OFFPUB/KSDA-07-001/EN/KSDA-07-001-EN.PDF

Freeman, J. L. (1955). The political process. Garden City: Doubleday.

Freudmann, A. (October 21, 1999). Europe taxed by box-size diversity. Journal of Commerce, 1.

Greenwood, J. (2005). Interest Representation in the European Union. Basingstoke: Palgrave.

Héritier, A., \& Eckert, S. (2008). New Modes of Governance in the Shadow of Hierarchy: Selfregulation by Industry in Europe. Journal of Public Policy, 28(1), 113-138.

Héritier, A., \& Lehmkuhl, D. (2008). Introduction: The Shadow of Hierarchy and New Modes of Governance. Journal of Public Policy, 28(1), 1-17.

Héritier, A., \& Lehmkuhl, D. (2011). Governing in the Shadow of Hierarchy: New Modes of Governance in Regulation. In A. Héritier \& M. Rhodes (Eds.), New Modes of Governance in Europe: Governing in the Shadow of Hierarchy (pp. 19-47). Palgrave Macmillan.

Héritier, A., \& Rhodes, M. (Eds.). (2011). Governing in the Shadow of Hierarchy: New Modes of Governance in Regulation. Cambridge: Palgrave Macmillan.

ICF Consulting. (2003). Economic Analysis of Proposed Standardisation and Harmonisation Requirements. Final Report 13 October 2003.

ISO.(2005). FAQ. Retrieved from http://www.iso.org/iso/en/faqs/faqstandards.html

Jordan, A., Wurzel, R. K. W., \& Zito, A. (2005). The Rise of 'New' Policy Instruments in Comparative Perspective: Has Governance Eclipsed Government? Political Studies, 53.

Knill, C., \& Lehmkuhl, D. (2002). Private actors and the state: Internationalization and changing patterns of governance. Governance: An International Journal of Policy, Administration, and Institutions, 15(1), 41-63.

Landmarks Publications. (2003). European public affairs directory (Landmarks, Ed.). Brussels.

Lasswell, H. (1958). Politics: What Gest What, When, How. Cleavland: Meridian books.

Lehmann, W. (2009). The European Parliament. In D. Coen \& J. Richardson (Eds.), Lobbying the European Union: Institutions, Actors and Issues (pp. 70-69). Oxford: OUP.

Levinson, M. (2006). The box: how the shipping container made the world smaller and the world economy bigger. Princeton University Press.

Majone, G. (1996). Regulating Europe. Taylor \& Francis.

Mayntz, R., \& Scharpf, F. W. (1995). Steuerung und Selbstorganisation in staatsnahen Sektoren. In R. Mayntz \& F. W. Scharpf (Eds.), Gesellschaftliche Selbstregulierung und Politische Steuerung (pp. 9-38). Frankfurt: Campus.

McCubbins, M., Noll, R., \& Weingast, B. (1987). Administrative procedures as instruments of political control. Journal of Law, Economics, and Organization, 3(2), 242-77.

OECD. (2003). Voluntary Approaches for Environmental Policy: Effectiveness, Efficiency and Usage in Policy Mixes (OECD, Ed.). Paris: OECD.

OECD. (1999). Voluntary Approaches for Environmental Policy: An Assessment (OECD, Ed.). Paris: OECD. 
Peltzman, S. (1984). Constituent interest and congressional voting. JL \& Econ. 27, 181.

Pollack, M. (1997). Delegation, agency, and agenda setting in the european community. International Organization, 51(1), 99-134.

Porter, M. E. (1979, May). The Structure Within Industries and Companies' Performance. Review of Economics and Statistics, 61, 214-227.

Powell, W.W. \& P. J. DiMaggio (Eds.), The New Institutionalism in Organizational Analysis (pp. 63-82). Chicago: University of Chicago Press.

Radaelli, C. (1999). The public policy of the European Union: whither politics of expertise? Journal of European Public Policy, 6(5), 757-774.

Rhodes, M., \& Visser, J. (2011). Seeking Commitment, Effectiveness and Legitimacy: New Modes of Socio-Economic Governance in Europe. In A. Héritier \& M. Rhodes (Eds.), New Modes of Governance in Europe: Governing in the Shadow of Hierarchy (pp. 104-134). Palgrave Macmillan.

Sabatier, P. (1988). An advocacy coaltion framework of policy change and the role of policy learning. Policy Sciences, 21, 129-68.

Scharpf, F. W. (2006). The joint-decision trap revisited. Journal of Common Market Studies, 44(4), 845-864.

Schmidt, S. K., \& Werle, R. (1993). Technical controversy in international standardization. MPIFG Discussion Paper, (March 1993).

Schmitter, P., \& Streeck, W. (1985). Community, Market and the State - and Associations? The Prospective Contribution of Interest Governance to Social Order. European Sociological Review, 1, 119-138.

Sirbu, M., \& Zwimpfer. (1985). Computer communications standards: the case of dx.25. IEEE Communications, 32(3, March), 35-45.

Stares, J. (2006, Aug. 25). Brussels has rethink on banning the $45 \mathrm{ft}$ container: Transport commissioner Barrot tells MEPs of EC's 'new approach to logistics'. Lloyd's List, 3.

Stigler, G. (1975). The citizen and the state: Essays on regulation. University of Chicago Press Chicago.

Wahl, D. (January 23, 2009). Grüner Horizont. Verkehrs Rundschau,(4), 15. 
Political Contestation in the Shadow of Hierarchy

\section{Appendix}

Figure 1: Pallet-loading capacity of the ISO 40 foot container

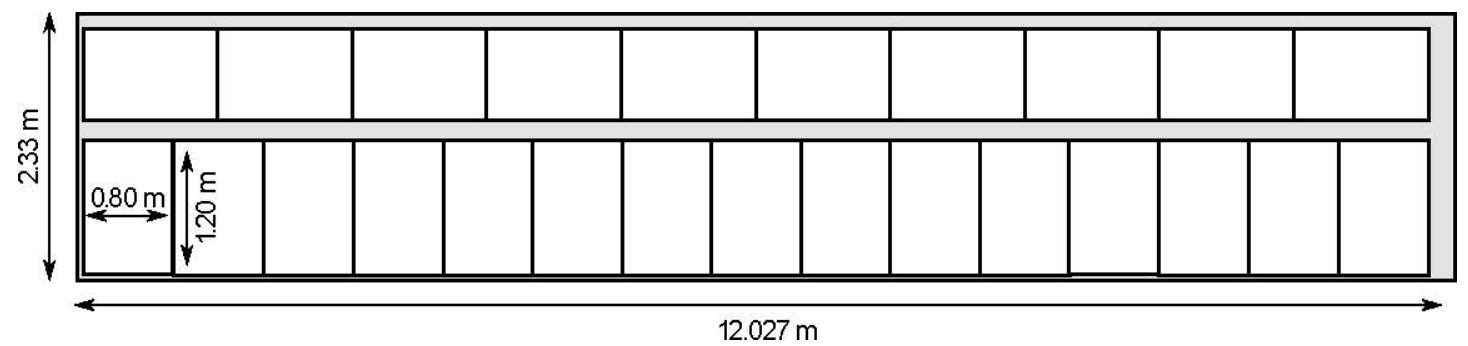

Table 1: Modal preferences

\begin{tabular}{|l|c|c|c|c|c|}
\hline & $\begin{array}{l}\text { Stack- } \\
\text { ability }\end{array}$ & $\begin{array}{l}\text { Top- } \\
\text { liftability }\end{array}$ & $\begin{array}{l}\text { Low tare- } \\
\text { weight }\end{array}$ & $\begin{array}{l}\text { Pallet- } \\
\text { width }\end{array}$ & $\begin{array}{l}\text { High } \\
\text { cube }\end{array}$ \\
\hline Road & & & $\mathrm{x}$ & $\mathrm{x}$ & $\mathrm{x}$ \\
\hline Rail & & & & $\mathrm{x}$ & \\
\hline Deep Sea & $\mathrm{x}$ & $\mathrm{x}$ & & & $\mathrm{x}$ \\
\hline $\begin{array}{l}\text { Inland } \\
\text { waterways }\end{array}$ & $\mathrm{x}$ & $\mathrm{x}$ & & & \\
\hline Combined & & & & $\mathrm{x}$ & $\mathrm{x}$ \\
\hline
\end{tabular}

Figure 2: Pallet-loading capacity of the proposed European intermodal loading unit

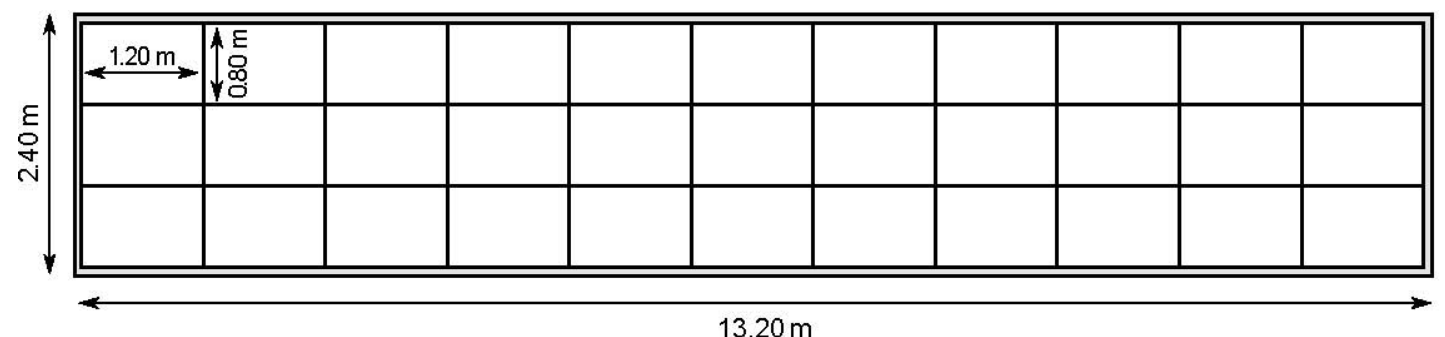

$13.20 \mathrm{~m}$ 


\section{Recent LEQS papers}

Hyman, Richard. 'Trade Unions, Lisbon and Europe 2020: From Dream to Nightmare' LEQS Paper No. 45, December 2011

Wagner, Peter. 'The democratic crisis of capitalism: Reflections on political and economic modernity in Europe' LEQS Paper No. 44, December 2011

Chalmers, Damian \& Chaves, Mariana. 'The Reference Points of EU Judicial Politics' LEQS Paper No. 43, September 2011

Hassel, Anke. 'The paradox of liberalization - Understanding dualism and the recovery of the German political economy' LEQS Paper No. 42, September 2011

Hancké, Bob. 'Endogenous Coordination: Multinational Companies and the Production of Collective Goods in Central and Eastern Europe' LEQS Paper No. 41, August 2011

Crescenzi, Riccardo, De Filippis, Fabrizio \& Pierangeli, Fabio. 'In tandem for cohesion? Synergies and conflicts between regional and agricultural policies of the European Union' LEQS Paper No. 40, July 2011

Somek, Alexander. 'The Social Question in a Transnational Context' LEQS Paper No. 39, June 2011

Mabbett, Deborah. 'A Rights Revolution in Europe? Regulatory and judicial approaches to nondiscrimination in insurance' LEQS Paper No. 38, May 2011

Karaman, K. Kıvanç \& Pamuk, Şevket. 'Different Paths to the Modern State in Europe: The interaction between domestic political economy and interstate competition.' LEQS Paper No. 37, May 2011

Scharpf, Fritz W.. 'Monetary Union, Fiscal Crisis and the Preemption of Democracy.' Paper presented at the LEQS Annual Lecture 'Saving the Euro - at the expense of democracy in Europe?' on 12 May 2011 at the London School of Economics, LEQS Paper No. 36, May 2011

Zigante, Valentina. 'Assessing Welfare Effects of the European Choice Agenda: The case of health care in the United Kingdom.' LEQS Paper No. 35, May 2011

Hobolth, Mogens. 'European visa cooperation: interest politics and regional imagined communities.' LEQS Paper No. 34, May 2011

Monastiriotis, Vassilis. 'Regional Growth Dynamics in Central and Eastern Europe.' LEQS Paper No. 33, April 2011

Johnston, Alison. 'The Revenge of Baumol's Cost Disease?: Monetary Union and the Rise of Public Sector Wage Inflation.' LEQS Paper No. 32, March 2011

Glendinning, Simon. “Europe, for example.' LEQS Paper No. 31, March 2011

Winkler, Heinrich August. 'Greatness and Limits of the West. The History of an Unfinished Project.' LEQS Paper No. 30, February 2011

Dani, Marco. 'Assembling the fractured European consumer.' LEQS Paper No. 29, January 2011

Joerges, Christian. 'Unity in Diversity as Europe's Vocation and Conflict's Law as Europe's Constitutional Form.' LEQS Paper No. 28, December 2010 
LEQS

European Institute London School of Economics Houghton Street WC2A 2AE London

Email: euroinst.LEQS@lse.ac.uk

\section{http://www2.lse.ac.uk/europeanInstitute/LEQS/Home.aspx}

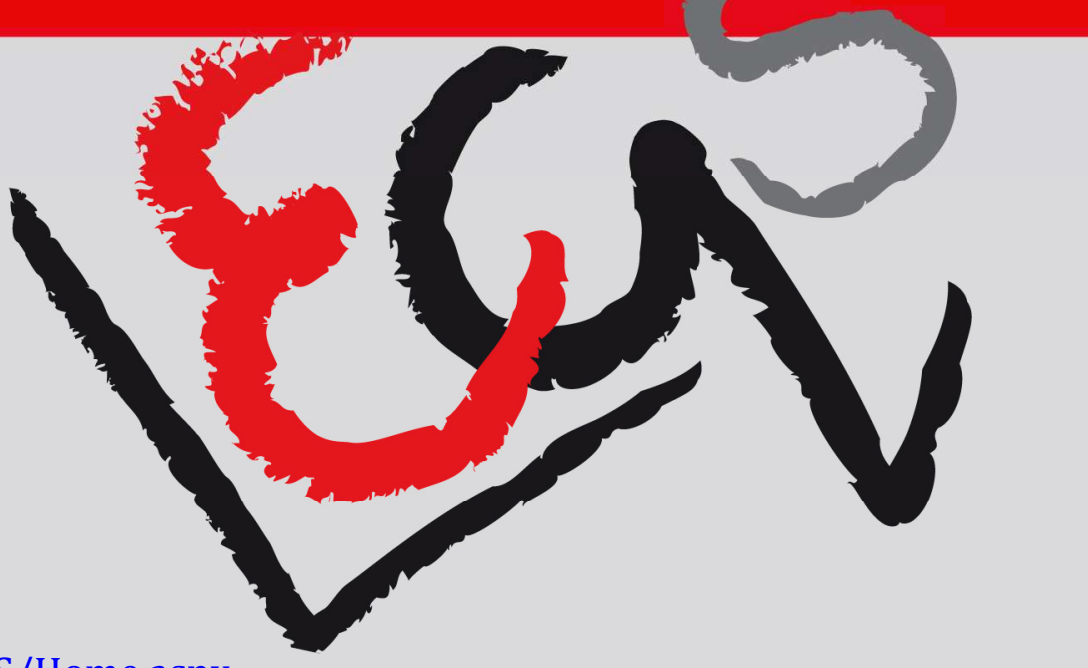

